ně dokázali reflektovat vlastní ideologické pozice, abychom je dokázali porovnat s obrazy jiných, vést s nimi debatu a pochopit díky nim jejich záměry a motivace. Můžeme tak odhalit ,,prázdnotu“ či ,,nedostatečnost“" vlastních obrazů, aniž bychom museli tvrdit, že je nepotřebujeme, nebo museli předstírat, že jsme je nevyrobili.

Metodologickou slabinu tvoří snad až příliš široké pojetí obrazu. Autor se svou definicí obrazu příliš nezaobírá a nechává ji spíše intuitivně vyplynout $\mathrm{z}$ předloženého textu. Místy tak dává více prostoru $\mathrm{k}$ dezinterpretacím, než je dle mého názoru nutné. I tak ale nemohu jinak než knihu vřele doporučit.

FRANTIŠEK VÁLEK

Religio: Revue pro religionistiku 29/1, 2021, 98-100

https://doi.org/10.5817/Rel2021-1-8

This work can be used in accordance with the Creative Commons BY-NC-ND 4.0 International license terms and conditions (https://creativecommons.org/licenses/by-nc-nd/4.0/).

\section{Joseph P. Laycock, Speak of the Devil: How The Satanic Temple is Changing the Way We Talk about Religion,}

\section{New York: Oxford University Press 2020, 272 p.}

\section{ISBN 978-0-190-94849-8.}

Since its beginnings in 2012, The Satanic Temple (TST) has attracted attention through different activities and campaigns that have become part of national public debates and various U.S. lawsuits. Amongst many other activities, the controversial attempt to erect a satanic statue of Baphomet has played an important role. The monument was meant to be installed on the grounds of the Oklahoma State Capitol in protest against the installation of the Ten Commandments Monument. Taking advantage of the political controversy around the monument, TST, within its secularistic ideology, sought to promote the separation of state and religion. TST claimed that either no religion should be privileged and associated with the state (including its buildings and properties), or all religions should be allowed to install their monuments on the basis of religious freedom. This TST initiative has been part of its broader focus on fighting the dominance of particularly evangelical Christianity in the U.S. public space.

It can be said that TST has fundamentally changed the satanic milieu and has established a "new" paradigm of non-theistic Satanism based explicitly on Satanist public activism, where Satan is conceived as a symbol of the anti-authoritarian rebel. For TST, the "new" satanic paradigm is reflected explicitly in the struggle for social justice, religious freedom, women's equality, and the rights of minorities, including the LGBTQ community. In comparison to organizations such as the Order of Nine Angles, which have inclined towards far-right ideologies, TST essentially enters the field of left-wing activism and stands at the opposite pole of the satanic milieu.

The genesis and development of TST in the U.S. is the main focus of the book Speak of the Devil by Joseph Laycock, an associate professor of religious studies at Texas State University, who focuses on American religious history, moral panics, and new religious movements. The title of Laycock's book also promises an overlap with the discussion about what can be perceived as a religion or what is referred to as a religion in public discourse. This means that the author's aim is not only to offer a historical survey of TST but also to explore "the movement's effects on public discourse" (p. 24) and to deal with the question of "how TST is challenging popular understandings of what religion is" (p. 25). For that reason, Laycock analyses different TST campaigns that have resulted in various public controversies and several lawsuits, and broader public discussions about TST. 
The first two chapters, "The Day Satan Came to Oklahoma" and "Origins and History of The Satanic Temple", provide a descriptive account of how TST came into being as a small group of sympathizers around Lucien Greaves and Malcolm Jarry. In addition, the chapters document the development of the organization and introduce the campaigns that have attracted considerable public attention. Laycock's narrative style is fluent and readable, although the content of the opening chapters themselves lacks the overlap with the broader context of the academic study of Satanism or new religious movements.

This overlap, however, is gradually developed in the third chapter, "Satanic Schisms", in which Laycock shows the internal contradictions and divisions in TST that new religious movements, including Satanism, often go through as they evolve. Laycock also describes efforts to purify TST by some of its members. This was reflected, for example, in accusations of sexism, racism, and support for the alternative right, not excluding accusations against TST founder Lucien Greaves. These tendencies have been manifested, although TST is highly egalitarian and, as Laycock writes, "TST may be the most diverse Satanic organization that has ever existed" (p. 77). This may indicate further tendencies not only within TST membership but in the satanic milieu in general. TST might thus be just a precursor to even more radical left-wing satanic groups.

The following chapter, "The Satanic Reformation", addresses the relationship between TST and the Church of Satan (CoS). CoS, founded in the 60s, had previously been the most prominent Satanist organization, and its founder, Anton LaVey, essentially defined the dominant paradigm of modern Satanism. Initially, even a part of TST's membership inclined to CoS. At present, however, both groups find themselves in a competitive struggle, in which $\mathrm{CoS}$ accuses TST of fake Satanism. By this, the author aims to illustrate the problem of tradition and creating authenticity. CoS puts itself in the position of representing authentic Satanism on the basis of its claims of having established a tradition. However, in the context of tradition shaping, TST claims a tradition too, as it refers to the concepts of Romanticism dating back to the $19^{\text {th }}$ century, with further references to William Blake, Percy Bysshe Shelley, John Milton and Lord Byron and their iconic works presenting Satan as a tragic rebel. TST thus inclines closer to an egalitarian social critique than to the orientation of $\mathrm{CoS}$ based on social Darwinism. One can thus identify the author's tendency to present TST and their political and philosophical stances in contrast to LaVeyan Satanism. Moreover, the author seems to favour TST, which is introduced in a positive light as a progressive reformed Satanism in contrast to his depiction of $\mathrm{CoS}$ as a conservative Satanism of the past. Furthermore, Laycock's comments on Romantic movements and authors of the early nineteenth century seem in some respects lacking in the degree of proper contextualization required to provide sufficient articulation of socio-symbolic references. Laycock also briefly discusses the definition of Satanism in this chapter. However, one would expect a deeper discussion of what can be considered Satanism from an academic point of view rather than simple application of Benedict Anderson's concept of imagined community to Satanism.

The following chapter, "Religion or Trolls", is most relevant to the subtitle "How The Satanic Temple is Changing the Way We Talk about Religion". From the beginnings of TST, there has been public discussion about whether TST is, in fact, merely a prank. Another argument against the recognition of TST as a religion is the accusation that TST promotes only political activism. As Laycock writes (p. 103): "Implicit in the argument that TST are 'trolls, not a religion' is a claim about the nature of 'religion' as a discrete discourse that is hermetically sealed from both politics and satire." The author shows that religion does not have to be exclusive of politics and satire, and within TST, these elements seem to work together. According to the founder, Lucien Greaves, TST was not only meant as a joke but always had a basis in Satanic ideology. Since TST is not related to the supernatural, and Satan is not a real supernatural being, society struggles to accept 
TST as a religion. Therefore, TST sought to declare that it is a religion, despite claiming allegiance to non-theistic Satanism. Therefore, they attempted to emphasize TST's own moral beliefs, code, rituals, and community.

Laycock accepts this perspective and accordingly defines TST as a religion. In connection with public "battles" over the question of religion, Laycock, however, with references to Russell McCutcheon, asserts that "an interesting thing to study, then, is not what religion is or is not, but 'the making of it', the process itself" (p. 205). Laycock's contribution in this chapter is not a description of how TST meets or does not meet the criteria of the academic definition of religion. Rather, the author shows how the dynamic formation of a socially constructed category of religion is being transformed in public debates about TST in American society. Moreover, he deals with the criteria for perceiving a phenomenon as a religion and their implications for the political and social field. Public discussions about TST show what requirements a religion is expected to meet in the U.S. public space so that it can be taken seriously as a religious actor and enter into public debates. Laycock asserts that this is also the reason why TST tries to be considered a religion (p. 125): "While I have defended the position that TST is a 'real religion' - and arguably becoming more 'real' with each ritual and chapter meeting - it would be a mistake to ignore that there is a provocation built into their claim to be a religion. TST became a religion as they attempted to participate in a larger conversation about religious freedom." In public debates, TST draws on the potential of Satanism as a controversial label which in American society ensures public and media attention. Overall, Laycock shows how religion is shaped and produced in power games in public debates. Moreover, within these debates, he reveals the implicit model of religion based on evangelical Christianity in the U.S. Discussions about TST and public perceptions of what religion is and what it is not have challenged some of the criteria of the mentioned implicit model of religion. As
Laycock writes, "TST has drawn controversy not because they have conformed to popular criteria about what a religion ought to look like but rather because they have openly challenged these criteria - especially the idea that religion is fundamentally about supernaturalism" (p. 105).

The next chapter, "Satanic Bake Sales", describes the strategies by which TST tries to act in the public space not as a representative of evil but in a positive, socially responsible light. For example, TST carries out various charitable activities or events in schools to compete with Christian (after-) school programs, though these cannot escape the very negative connotations associated with Satanism. As Laycock explains, Christians aim to avoid the presence of Satanists in shared spaces at almost any cost, even if it means not attending a planned event.

The penultimate chapter, "Taking Equality Too Far", describes the institutional limits that appeared when TST publicly tried to act as one of the religions. As an example, Laycock mentions TST's attempt to participate in prayer invocations before city councils. This resulted in the introduction of new restrictions on prayer invocations to prevent TST from participating. Despite the declaration of religious freedom, equality and tolerance, the presence of Satanism in the public sphere is inconceivable for some legislators and public officials and sometimes provokes a panic reaction.

In "Conclusion", Laycock highlights the importance of discussion in the field of Satanism, claiming that "TST - and by extension religious Satanism - matters because this reaction is part of a conversation in which the core values of American society are negotiated" (p. 187). He discusses TST in the context of Massimo Introvigne's pendulum theory about the cycle of Satanism and anti-Satanism. Laycock further develops the argument by exploring the American identity formed by the concept of the City upon a Hill, which is predestined to triumph over Satan. America might be seen as a Christian nation where Satan represents evil forces attacking the values of the na- 
tion. Moreover, Satan might represent "the other", which Laycock links to the dawn of the American nation, referring to accusations of indigenous people and slaves making pacts with the devil in the past. From today's perspective, Laycock understands TST's Satanism in terms of its main focus on the critique of society and the demonstration of its own values. According to Laycock, TST is not intended to offer "a replacement for the myth of a Christian nation, but a corrective to it and a decentering of it" (p. 193).

To conclude, Laycock discusses the controversies linked to the statue of Baphomet that TST members wanted to erect next to the Ten Commandments Monument in front of the Capitol. By this, he addresses a question that has polarised American society in particular - the question of whether TST's Satanism can be considered a religion. After discussing the relevancy of history and tradition and their role in the constitution of religious systems, the author uncovers an acute problem residing in American society's values in relation to individual rights, including the freedom of religion guaranteed by the First Amendment. As Laycock claims, "TST forces us to consider what 'religion' means for a country that promises religious freedom" (p. 104). Although the United States presents itself as a free and religiously pluralistic society, the TST case shows the limits of socially acceptable religious plurality and reveals the Christian roots of American society, for which Satan is hardly acceptable even as a symbol in public space.

Speak of the Devil ranks its author among influential scholars of contemporary Satanism, such as, among others, Jesper Petersen, Massimo Introvigne, and James Lewis. What might be seen as problematic regarding Laycock's book is his apparent sympathy towards TST, which seems to be presented as a favourable form of Satanism and as a benefit to American freedom and religious plurality. Clearly, the book is the result of a long-term study of TST, which is evidenced by a large number of references to the author's own interviews with TST members from different periods and by analyses of many different controversies and public discussions about TST across the U.S. However, some parts of the book might be considered rather too descriptive. Nevertheless, overall, Laycock's work is likely to appeal to both scholars and a broader audience by presenting a fluent, readable, and properly contextualized analysis of the development of The Satanic Temple.

\section{MIROSLAV VRZAL - IVONA VRZALOVÁ}

\section{Religio: Revue pro religionistiku} 29/1, 2021, 100-103. https://doi.org/10.5817/Rel2021-1-9

This work can be used in accordance with the Creative Commons BY-NC-ND 4.0 International license terms and conditions (https://creativecommons.org/licenses/by-nc-nd/4.0/). 